УДК 612.017.2

\author{
М. В. Горіла \\ Дніпропетровський національний університет ім. Олеся Гончара \\ НЕІНВАЗИВНІ МЕТОДИ ДІАГНОСТИКИ - \\ СТАН ПРОБЛЕМИ ТА ПЕСПЕКТИВИ РОЗВИТКУ
}

Розглянуто проблеми розвитку неінвазивних методів діагностики. Класифіковано галузь неінвазивної діагностики за видами методів, що використовуються, типами збираних зразків. Обговорено переваги та недоліки різних методів неінвазивної діагностики. Представлено внесок кафедри біофізики та біохімії Дніпропетровського національного університету у розвиток неінвазивних методів діагностики безпосередньо у практичному плані.

$$
\begin{gathered}
\text { M. V. Gorelaya } \\
\text { Oles 'Gonchar Dnipropetrovs'k National University } \\
\text { NON-INVASION DIAGNOSTIC METHODS - } \\
\text { STATE OF ART AND PROSPECTS OF DEVELOPMENT }
\end{gathered}
$$

The progress of non-invasion diagnostic methods is under examination. Non-invasion diagnostic branch was classified according to using methods and obtained samples. The advantages and shortcomings of different non-invasion diagnostic methods were discussed. The contribution of Department of Biophysics and Biochemistry of Dnipropetrovsk National University into the progress of non-invasion technology was presented.

\title{
Концептуальні засади
}

Неінвазивну діагностику вважають одним із пріоритетних напрямків медичних досліджень у всьому світі. Цей тип діагностики визначають як «безкровний», «безболісний», «нешкідливий». Таке нове діагностичне спрямування в медицині зародилося наприкінці 1980-х років. Але у переліку сучасних методів діагностики, заснованих на визначенні морфологічних, функціональних, біохімічних і генетичних парметрів організму, неінвазивні методи посідають ще досить незначне місце. Важливість таких методів, особливо у медичній практиці майбутнього, важко переоцінити.

Існують декілька потужних факторів, які сприяють появі нових неінвазивних методів. До них належать: по-перше, розвиток методів так званої домашньої діагностики, що було пов'язано з появою понад 15 років тому технології “сухої хімії”; по-друге, у зв’язку з небезпекою інфікування ВІЛ та іншими хворобами проколювання шкіри перестало бути безпечною процедурою, незважаючи на одноразовий інструментарій; потретє, проведення масових профілактичних оглядів також потребувало відмови від узяття зразка крові, бо важко довести здоровій людині таку необхідність; по-четверте, технічний прогрес дозволив мініатюризувати прилади, необхідні для проведення “діагностики вдома". Сучасні електронні технології дають можливість створити прилади розмірами не більше олівця або записної книжки $[7 ; 9 ; 10]$. У нинішній час у світі понад п’ятдесят груп дослідників розробляють нові методи неінвазивної діагностики.

(C) М. В. Горіла, 2009 
Найбільш відомими є "Furtex", "Medisence" із США та деякі інші. Мета даної роботи описати та охарактеризувати сучасний стан проблеми та перспективи розвитку неінвазивної діагностики.

\section{Характеристика методів неінвазивної діагностики}

В основу класификації методів неінвазивної діагностики покладені різні критеpiї. Перша - класифікація, заснована на апаратно-методичному арсеналі. До цієї групи методів неінвазивної діагностики, наприклад, входять такі дослідження, як неінвазивна оптична та лазерна медична діагностика, яка грунтується на тому, що всі основні біохімічні та клітинні компоненти тканин та крові мають характерні “індивідуальні” спектри поглинання, відбиття, розсіяння та люмінесценції. Ці спектри різні для різних м'яких тканин та ділянок ущільнень у них, для окисненого та відновленого стану молекул у клітинах тканини. Загальний відсотковий вміст різних біохімічних і анатомоморфологічних компонентів у тканинах різний для стану норми та захворювання органів і систем організму. Тобто загальний функціональний і патофізіологічний стан тканин відбивається на їхніх оптичних властивостях, які можуть бути зареєстровані методами лазерного спектрального аналізу, спектроскопії розсіяння та поглинення, іншими оптичними методами. Введено навіть спеціальний термін для більшості таких методів біоспектрофотометрія $[7 ; 10]$.

У наукових і деяких діагностичних лабораторіях здійснюються такі методи неінвазивної діагностики цієї групи: методи кардіогемодинаміки (пульсометрія, плетизмографія, тахоосцилографічне вимірювання артеріального тиску тощо); методи реєстрації фізичних властивостей шкірних покривів (електричний імпеданс, в'язко-пружні властивості шкіри та підлеглих тканин, вологість епідермісу); реєстрація функцій зовнішнього дихання (спірометрія, дихальні рухи).

Один комп'ютерний блок із відповідними електродами та первинними датчиками дає в руки дослідників цілий набір методів. Висока гнучкість системи, тобто можливість розширення та комбінації методів, вибору різних засобів обробки сигналу та подання даних вимірювань, роблять комплекс зручним як для медико-біологічних досліджень, так і для навчання студентів методів неінвазивної діагностики. Апробація автоматизованого комплексу повністю підтверджує необхідність упровадження блочного принципу конструкції діагностичної апаратури у науково-дослідні, клінічні та навчальні лабораторії, а також у медичне приладобудування [9; 11].

Наступний критерій класифікації методів неінвазивної діагностики - це класифікація, заснована на способах збирання зразків для аналізу. Даний розділ містить у собі такого типу дослідження, як аналіз природних рідин живих організмів, повітря, що видихається, аналіз стану капілярів, поверхні шкіри та глибше розташованих тканин. Найдослідженішою та вивченішою з біорідин є, звичайно, сеча. Але і зараз із успіхом вдається відкривати та впроваджувати нові методи дослідження сечі неінвазивного плану: створення автоаналізаторів для хімічного аналізу компонентів сечі (уринаналізу) та дослідження елементів осаду сечі, дефекти розвитку плода можна діагностувати за допомогою аналізу трансренальної РНК [10].

Винятково важливого значення набуває дослідження слини, зокрема таких іiї показників, як уміст високомолекулярних пептидів та олігопептидів середньої молекулярної маси, ії електропровідності під час масових досліджень населення екологічно несприятливих місць мешкання з метою виявлення серед дорослого та дитячого контингенту осіб із ранніми доклінічними відхиленнями у процесах обміну, викликаними наявністю у навколишньму середовищі екотоксикантів. Аналіз слини також дозволяє діа- 
гностувати уремію за збільшенням умісту сечовини та залишкового азоту, ураження паренхіми печінки - за їх зниженням, гіпер- та гіпотиреозу - за змінами кількості та форм йоду, високу гіперглікемію - за підвищенням рівня глюкози (під час невеликої гіперглікемії він у слині нормальний), визначити групу крові, інфаркт міокарда, поставити ранній діагноз інфекційно-запальних ускладнень після перелому щелепи, виявити порушення функцій окремих слинних залоз та інші види порушення обміну речовин в організмі. У слину з крові переходять стероїди та ряд лікарських препаратів, що має значення під час оцінки гормонального статусу та динаміки лікарських препаратів у організмі [13].

Результати цитологічних та біохімічних аналізів мокроти, сечі, поту, слизу, конденсату вологи видихненого повітря, навіть без аналізу динаміки цих ознак під час функціональних проб, містять значно більше інформації про процеси життєдіяльності, ніж зараз прийнято вважати [14-16].

Аналіз слізної рідини дозволяє діагностувати уремію за збільшенням рівня залишкового азоту або сечовини, урикемію за збільшенням сечової кислоти, гіперхолістеринемію за збільшенням холестерину, вісім типів спадкових глікозидозів за змінами активності глікозидаз, прогнозувати рецидив офтальмогерпесу за появою лактатдегідрогенази та підвищенням активності малатдегідрогенази та глікозидаз (раніше за клінічні симптоми рецидиву), проводити скринінг цукрового діабету паперовими тестсмужками тощо.

За активністю ензимів та ізоензимів у мокротах і бронхіальних змивах можна підтвердити діагноз пневмонії, астми, раку легенів.

Для характеристики різних патологічних процесів установлені особливості зв'язку між цитологічними та біохімічними ознаками різних рідких середовищ організму, між цитологічними елементами мокроти та характеристиками спірограми, між електроенцефалограмами та диханням тощо.

Застосування у клінічній біохімії сльози, рідин ротової порожнини, мокроти або бронхіальних змивів замість крові є атравматичним, безболісним, дозволяє багаторазово повторювати аналізи, знижує вірогідність інфікування будь-якими збудниками хвороб, у тому числі й вірусом СНІДу.

Третій критерій класифікації методів неінвазивної діагностики - класифікація, заснована на діагностичному оцінюванні роботи окремих органів та їх систем. На першому місці у даному випадку розташувалися неінвазивні методи дослідження кровоносної системи, починаючи з капіляроскопії, пульсоксиметрії, лазерної доплерівської флуометрії, флюоресцентної діагностики та закінчуючи застосуванням оптичного (у тому числі лазерного) опромінення для зондування тканин і органів пацієнта 3 метою отримання за відбитим (розсіяним, що пройшло тканини наскрізь) світлом діагностичної інформації щодо біохімічного складу та анатомічної (морфологічної) будови досліджуваної ділянки м'яких тканин тіла пацієнта [10; 12].

Діагностика роботи репродуктивної системи також дуже важлива як у плані демографічної ситуації, так і у плані збереження здоров'я нації у цілому. У даному випадку слід відзначити бурхливий розвиток імунохроматографічного аналізу із застосуванням прямої мітки та методів сухої хімії. За останні два роки з'явилося понад 40 видів нових тест-систем, заснованих на використанні неінвазивних підходів для оцінки фізіологічних станів: визначення ранніх термінів та перебігу вагітності (хоріотропін у сечі), часу овуляції (лютропін у сечі), та для діагностики інфекційних (антиген ВІЛ у слині, антиген хламідій та специфічний фермент гонококів в урогенітальних мазках, 
ендокринних (фолітропін, пролактин у сечі тощо), онкологічних (прихована кишкова кровотеча) захворювань.

Імунохроматографічні тести, що спираються на тонкошарову хроматографію та суху хімію, не потребують додаткового обладнання, спеціальних умов зберігання, виконуються у будь-яких умовах протягом 20 хвилин. Для проведення реакції необхідно додати досліджуваний зразок і візуально якісно або напівкількісно оцінити результати аналізу. Тест-системи даного покоління ефективно використовуються як у клінічних лабораторіях, так і в кабінеті лікаря, під час надання швидкої та невідкладної допомоги, у домашніх умовах.

Існує й дещо інша класифікація методів неінвазивної діагностики. По-перше, це методи кардіогемодинаміки, наприклад, капіляроскопія. По-друге, методи реєстрації фізичних властивостей шкірних покривів. По-третє, реєстрація функції зовнішнього дихання. По-четверте, дослідження складу виділених живим організмом біорідин.

Важливо також обговорити переваги та недоліки методів неінвазивної діагностики. Досягнення в розвитку неінвазивних методів діагностики у клінічній лабораторній діагностиці за останні роки стосуються розширення спектра досліджених біорідин, отриманих неінвазивним шляхом, накопичення даних про концентрації у них різних компонентів, синхронності вимірювання концентрації компонентів у цих біорідинах 3 їх динамікою у крові, розвитку неінвазивних методів та приладів для безпосереднього виконання аналізу та отримання результату. Зокрема, дослідження у клінікодіагностичних лабораторіях інших біорідин, крім крові та сироватки, складають понад 50 \% від усієї кількості аналізів. Ця обставина може навіть розглядатися як недолік порівняно із сучасними біохімічними та імунологічними дослідженнями у крові та сироватці $з$ погляду спектра компонентів та інформативності результатів. Але сучасний розвиток лабораторних технологій, поява нових засобів лабораторного аналізу дозволяє поставити завдання радикальних змін ситуації та поновнення діагностичного арсеналу лабораторій. Підвищення інформативності неінвазивного лабораторного аналізу можна досягнути за рахунок об'єктивізації самого процесу лабораторного дослідження, використання методів, які дозволяють виключити суб'єктивну оцінку продукту реакції або диференціацію клітин на основі нових фізичних та хімічних принципів дослідження, засобів та приладів. Розробка на цій основі автоматизованих систем дозволяє розв'язати цю проблему для великих лабораторій. Наприклад, створення автоаналізаторів для хімічного аналізу компонентів сечі та дослідження осаду сечі $[5 ; 7 ; 16]$. До актуальних (які протребують розробки та впровадження) проблем галузі неінвазивної діагностики можна віднести наступні явища.

1. Виявлення та стандартизація умов отримання, транспортування та зберігання біоматеріалу на всіх етапах преаналітичної фази. Дотримання клінічним персоналом і персоналом лабораторій необхідних умов для отримання надійних результатів, виключення забруднення проб, у тому числі і компонентами, що зазвичай не зустрічаються в організмі людини.

2. Стандартизація умов одержання та виділення нормальних величин, у тому числі добір, характеристика та об'єм популяцій, умов проведення досліджень і отримання результатів, методи статистичного аналізу.

3. Конкретизація меж прийняття діагностичного рішення (нормальна, низька, висока патологічна концентрація).

4. 3'ясування діагностичного значення змін аналізів біорідини під час неінвазивних досліджень за різних фізіологічних і патологічних станів та контролю за лікуванням. 
5. Визначення ролі неінвазивних лабораторних досліджень ліків під час лікарського моніторингу.

На кафедрі біохімії та біофізики Дніпропетровського національного університету також $є$ розробки проблеми неінвазивної діагностики. Зокрема, успішно проводилися дослідження природних біорідин, які можна отримати без пошкодження будь-яких покривів та цілісності клітинних мембран [1-4].

За допомогою низки методів, які містили у собі імунохімічну складову, вивчали якісний та кількісний склад сечі людини. Аналізу піддавалися зразки сечі людей різної статі та вікових категорій, а також вагітних жінок, із метою оцінки функціонального стану гемосистеми, сечовивідної та ендокринної систем [2; 4].

У тісному співробітництві та для допомоги стоматологічній галузі медичних наук було розроблено та здійснено комплексне дослідження стоматологічних пацієнтів. Вивчено детальний склад слини, навколоясенної рідини та рідини із зубних карманів. Отримані дані дали змогу розробити рекомендації щодо оптимізації та поліпшення процесу лікування стоматологічних хворих [3].

Також були зроблені спроби проаналізувати інші рідини організму людини, зокрема слізну рідину та піт. Досліджували склад даних біорідин, отриманих від людей різного віку та статі, що належали до групи практично здорових осіб.

\section{Висновки}

Одержані результати дозволяють сформувати базу данних, яку згодом можна буде використовувати для визначення групи оптимальних показників, тобто групи так званої норми, з метою порівняння зі значеннями під час лікування різних захворювань. Подальший розвиток і вдосконалення методів неінвазивної діагностики беззаперечно актуальний і перспективний як із погляду фундаментальних досліджень, так і у плані прикладного застосування у різних галузях науки та практики.

\section{Бібліографічні посилання}

1. Горіла М. В. Дослідження вікових тенденцій розвитку хвороб парадонту // Биологические механизмы старения. Тез. V Междунар. симпоз. - Харьков, 2002. - С. 90.

2. Горіла М. В. Дослідження процесів протеїнурії та альбумінурії у дорослих та дітей за допомогою імунохімічних методів // Тези доп. Біохімічного з'їзду. - Чернівці, 2002. - С. 167.

3. Горіла М. В. Імунохімічне дослідження деяких сироваткових та гострофазних білків у нормі та за різних патологічних станів тканини парадонту // Вісник Дніпропетровського університету. Біологія. Екологія. - 2002. - Вип. 10, т. 2. - С. $29-31$.

4. Горіла М. В. Розробка методів масового скринінгу на протеїнурію та альбумінурію різних вікових груп населення // Вісник Дніпропетровського університету. Біологія. Екологія. - 2001. Вип. 9, т. 1. - С. 100-103.

5. Дадвани С. А. Неинвазивные методы диагностики брюшной аорты и артерий нижних конечностей / С. А. Дадвани, С. К. Терновой, Е. Г. Артюхина // Медицина. Хирургия. -2000. - 144 с.

6. Карп В. П. Скрининг-диагностика репродуктивных органов девушек и подростков / В. П. Карп, А. П. Никитин, Д. С. Чернавский // Вестник РАМН. - 2001. - № 5. - С. $38-43$.

7. Кательницкая Л. И. Неинвазивные методы скрининговой диагностики хронических неинфекционных заболеваний / Л. И. Кательницкая, Е. С. Глова, Л. А. Хаишева. - Ростов-на-Дону, 2008. $-56 \mathrm{c}$.

8. Корниенко Е. А. Хелпил-тест и хелик-тест для диагностики хеликобактериоза / Е. А. Корниенко, В. Л. Эмануэль, М. А. Дмитриенко. - М., 2005. - 75 с.

9. Лопухин Ю. М. Неинвазивная диагностика - настоящее и перспективы / Ю. М. Лопухин, А. С. Парфенов // Диагностика здоровья. - 1997. - № 6. - С. 126-129. 
10. Рогаткин Д. А. Перспективы развития неинвазивной спекрофотометрической диагностики в медицине / Д. А. Рогаткин, Л. Г. Лапаева // Медицинская техника. - 2003. - № 4. - С. 31-36.

11. Терновой С. И. Неинвазивная диагностика атеросклероза и кальциноза коронарных артерий / С. И. Терновой, В. А. Синицын, Н. Ю. Гагарина. - М., 2003. - 144 с.

12. Blakeley D. D. Noninvasive carotid artery tests predict stenosis / D. D. Blakeley, E. Z. Oddone // Ann. Intern. Med. - 1995. - Vol. 122. - P. 360-367.

13. Dzierzanowska-Fangrat K. Diagnosis of Helicobacter pylori infection / K. Dzierzanowska-Fangrat, P. Lehour // Helicobacter. - 2006. - Vol. 11. - P. 6-10.

14. Kearon C. Noninvasive diagnostics of deep venous thrombosis / C. Kearon, T. E. Newman, J. A. Julian // Ann. Intern. Med. - 1998. - Vol. 128. - P. 663-677.

15. Rautelin H. Diagnosis of Helicobacter pylori infection / H. Rautelin, P. Lehour, F. Megraud // Helicobacter. - 2003. - Vol. 8. - P. 13-20.

16. Wells P.S. Value of assessment of pretest probability of deep-vein thrombosis in clinical management / P. S. Wells, D. R. Andersen, J. Bormanis // Lancet. - 1997. - Vol. 350. - P. 1795-1798.

Надійшла до редколегії 11.10.2008 